\title{
Article
}

\section{Travel, Cultural Hybridity and Transnational Connections in Taiwanese Graphic Narratives}

\author{
Zemanek, Adina Simona
}

Available at http://clok.uclan.ac.uk/34421/

Zemanek, Adina Simona ORCID: 0000-0002-7960-8646 (2020) Travel, Cultural Hybridity and Transnational Connections in Taiwanese Graphic Narratives. European Journal of East Asian Studies, 19 (1). pp. 98-123. ISSN 1568-0584

It is advisable to refer to the publisher's version if you intend to cite from the work. http://dx.doi.org/10.1163/15700615-01901008

For more information about UCLan's research in this area go to http://www.uclan.ac.uk/researchgroups/ and search for <name of research Group>.

For information about Research generally at UCLan please go to http://www.uclan.ac.uk/research/

All outputs in CLoK are protected by Intellectual Property Rights law, including Copyright law. Copyright, IPR and Moral Rights for the works on this site are retained by the individual authors and/or other copyright owners. Terms and conditions for use of this material are defined in the policies page.

\section{CLoK}

Central Lancashire online Knowledge www.clok.uclan.ac.uk

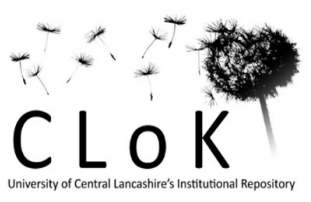




\title{
Travel, Cultural Hybridity and Transnational Connections in Taiwanese Graphic Narratives
}

\begin{abstract}
This study adopts a discursive analytical perspective to elaborate on transnational connections and cultural diversity as strategies for defining Taiwaneseness in graphic narratives published between 1997 and 2016. It considers the following aspects represented in the analysed texts: (1) processes of self-identification while travelling abroad; (2) depictions of Taiwan centred on familiar spaces open to outside cultural influences, which become locally appropriated through daily activities that link them to individual emotions and weave them into personal and collective memories; and (3) reaching beyond Taiwan to highlight transnational encounters and connections, thus placing the island within a global or regional framework of reference. The article assesses the degree to which this transnational viewpoint reproduces, challenges or complements existing notions regarding Taiwan's relations with China, Japan and the US, while also exploring relations established with other nodes of reference: Europe, New Zealand and Hong Kong. It also comments on the extent to which academic critical stances on Taiwan's multiculturalism and warnings against overlooking existing ties between Taiwan and the PRC in contemporary definitions of nationhood may hold true for the research material.
\end{abstract}

Keywords: Taiwan; graphic narratives; cultural hybridity; transnational connections; identity Introduction

\footnotetext{
Taiwan ... has been influenced by many outside factors, so it's hard for it to have its own culture ... look at what I'm wearing today, for instance - all these represent Taiwan's culture. I'm really an American boy, with Under Armor shoes, this T-shirt ... See, none of these bears a Taiwanese flavour. But what is this Taiwanese flavour? There is no such thing at all. (Ariel, graphic designer, interview, April 2017)
}
We are not the so-called China, we are the diverse Taiwan ... What we depict are features peculiar to our life. Maybe some of them, culture or religion, came from China, but many of our things are in fact a mixture ... this is the Taiwan I grew up in, and this is what foreigners would find interesting, I believe. (Ben, graphic designer, interview, April 2017)

Although frustrated with what they see as lack of a single, homogeneous cultural tradition, compensated in the recent nationalist discourse with traditions of contestable authenticity, the designers quoted above create tourist souvenirs that define Taiwan through ordinary, 
reassuringly familiar sights and objects always present in an everyday living environment, notwithstanding their cultural origin. Instead of essentialising Taiwan as a sign, such definitions, recurring in many popular texts beyond tourist souvenirs, ${ }^{1}$ highlight Taiwan's relationality and fluidity as meeting point of varied cultural influences.

During the martial law era (1947-87), the Kuomintang (KMT) government's claim to the mainland incorporated Taiwan into China as a centre of national identification, a process reinforced by the US Cold War policy positioning Taiwan as an allied 'free China' until 1979. ${ }^{2}$ Since the late 1980s, the trend of indigenisation has sought to define Taiwan as an entity distinct from a now othered China. The rewriting of national history redefined the Japanese colonial period, a fact reflected in academic writing, heritage-making and popular culture. The PRC's rise as world power, its increasingly aggressive nationalism and the strengthening of cross-strait economic ties have caused anxiety in Taiwan. In texts of popular culture, the still salient trope of colonial nostalgia goes so far as embracing Japan while rendering China invisible. Chris Berry explains this structuring absence as a strategy for dealing with the anxiety-inducing 'China factor' overshadowing Taiwan's future. ${ }^{3}$ The US has constituted another major point of reference. Taiwan's Cold War American ties gave rise to an elite cosmopolitanism propelled by a desire for education and dual citizenship as an 'exit ticket to a political safe haven in the event of war'. ${ }^{4}$

This study will look at definitions of Taiwan formulated in graphic novels and picture books, built upon transnational connections. It will consider three forms of relationality: (1) travel abroad as an incentive for national identification; (2) cultural hybridity within Taiwan; and (3) reaching beyond Taiwan in comparative approaches revealing linkages, similarities and novel perspectives. It will assess the extent to which China, Japan and the US still constitute reference frames for contemporary articulations of Taiwaneseness and will address the roles played by other regions such as Europe, Hong Kong or New Zealand.

\footnotetext{
${ }^{1}$ For a discussion of these themes as discourse formations, see Adina Zemanek, 'Getting to know Taiwan: borrowed gaze, direct involvement and everyday life,' in Positioning Taiwan in a Global Context: Being and Becoming, eds. Bi-Yu Chang, Pei-Yin Lin (Abingdon: Routledge, 2019), 161-77.

${ }^{2}$ Shu-mei Shih, 'Forum 2: linking Taiwan Studies with the world', International Journal of Taiwan Studies 1
} (2018): 213.

${ }^{3}$ Chris Berry, 'Imagine there's no China. Wei Te-Sheng and Taiwan's “Japan Complex”, , in Taiwan Cinema: International Reception and Social Change, eds Kuei-fen Chiu, Ming-yeh T. Rawnsley and Gary D. Rawnsley (New York: Routledge, 2017), 111-21.

${ }^{4}$ Allen Chun, 'The coming crisis of multiculturalism in "transnational” Taiwan', Social Analysis 46, 2 (Summer 2002): 111. 


\section{Theoretical Considerations}

Instead of macro approaches discussing the origins of modern nationalism, state institutions and large-scale, elite-driven political and economic processes, recent studies turn towards micro-scale, vernacular understandings of the nation in established contemporary democracies. ${ }^{5}$ They challenge the identification of nationalism with political ideologies, and view it as 'a set of intersubjective meanings and affective orientations that give people a sense of self and guide their social interaction and political choices' ${ }^{6}$ They also distinguish between banal nationalism ${ }^{7}$ (pervasive but unseen discursive templates underlying everyday interaction) and everyday nationalism, which casts nationhood as 'reproduced by ordinary people doing ordinary things', 'neither invisible nor ubiquitous, but ... actively appropriated, manipulated, and enacted as a category of social practice by varied social actors in varied social contexts' ${ }^{8}$ Rather than discrete bodies - individuals, material things and assemblages of people and physical objects that ground or locate national feelings and identities - Peter Merriman and Rhys Jones highlight the processes by which these feelings and affects circulate between and take hold of bodies moving through specific spaces and sites, as well as 'affective regimes' - the relations, networks and tensions through which national feelings intermittently emerge. They elaborate on the 'mobility spaces and infrastructures' interwoven with sensations, emotions and memories, through which nationness is constituted and experienced. ${ }^{9}$

This micro, everyday perspective underscores 'a plurality of understandings of nation, thus opening up a category traditionally depicted in monocultural tones' ${ }^{10}$ Unlike 'abstract nationalist ideological constructions' that postulate uniformity across national space, sensual and affective everyday places as key sites for individual expression of national identity are profoundly heterogeneous. Apart from being actively produced in a local context, the nation

\footnotetext{
${ }^{5}$ Jonathan Hearn and Marco Antonsich, 'Theoretical and methodological considerations for the study of banal and everyday nationalism', Nations and Nationalism 24, 3 (2018): 594-605; Bart Bonikowski, 'Nationalism in settled times', Annual Review of Sociology 42 (2016): 427-49.

${ }^{6}$ Bonikowski, 'Nationalism in settled times', 428.

${ }^{7}$ As defined by Michael Billig in Banal Nationalism (London: Sage Publications, 1995).

${ }^{8}$ John Fox and Maarten van Ginderachter, 'Introduction: everyday nationalism's evidence problem', Nations and Nationalism 24, 3 (2018): 546.

${ }^{9}$ Peter Merriman and Rhys Jones, 'Nations, materialities and affects', Progress in Human Geography 415
} (2017): 606-7.

${ }^{10}$ Hearn and Antonsich, 'Theoretical and methodological considerations', 595. 
is also 'recreated out of global connections'. ${ }^{11}$ Tim Edensor highlights the importance of space in reinforcing national frames of reference, understood both as a unit of territorial administration and as familiar, emotion-laden landscapes. ${ }^{12}$ Edensor and Sumartojo discuss the home as 'a central node within relational networks' and the familiar, parochial surroundings of domestic spaces. ${ }^{13}$

This processual, performative approach to nationhood will be complemented with an equally processual, active perspective on identity. Instead of positing the existence of essentialised, reified, axiomatic identities, Stuart Hall explains identity as an unfolding process of representation 'across different, often intersecting and antagonistic discourses, practices and positions' intertwined with processes of globalisation and migration, the 'increasingly fragmented and fractured' 'points of temporary attachment to the subject positions which discursive practices construct for us'. ${ }^{14}$ Rogers Brubaker and Frederick Cooper ${ }^{15}$ distinguish between identity and nation as categories of practice and of analysis. They mention the reification of these notions by both lay actors and political entrepreneurs, in response to a need for emphasising sameness and belonging, organising or legitimising collective action. Academics acting as both analysts and protagonists of identity politics tend to reproduce reification by uncritically adopting categories of practice as categories of analysis. Brubaker and Cooper dismiss the concept of identity altogether, even in its constructive 'soft' version centred on fluidity and multiplicity, as too elastic to be effective as an analytical tool. Instead, they propose the ideas of narrative, public representation or the processual, active term of identification, either in the form of individual self-identification or external identification by state institutions monopolising the symbolic power to name and categorise.

Academic research is not a neutral discursive process, but one of constructing and framing the object of knowledge, which involves power, omissions, downplaying or overemphasising specific themes or cultural practices. ${ }^{16}$ In Taiwan, identity has been a hot academic topic since the 1990s. Quantitative surveys often rely on questions about Taiwanese identity as

\footnotetext{
${ }^{11}$ Tim Edensor and Shanti Sumartojo, 'Geographies of everyday nationhood: experiencing multiculturalism in Melbourne', Nations and Nationalism 24, 3 (2018): 556.

${ }^{12}$ Tim Edensor, National Identity, Popular Culture and Everyday Life (London: Berg, 2002).

${ }^{13}$ Edensor, National Identity, 560.

${ }^{14}$ Stuart Hall, 'Introduction: who needs identity?', in Questions of Cultural Identity, eds Stuart Hall and Paul du Gay (London: Sage Publications, 1996), 4, 6.

${ }^{15}$ Rogers Brubaker and Frederick Cooper, 'Beyond "identity"', Theory and Society 29 (2000): 1-47.

${ }^{16}$ Mark Harrison, Legitimacy, Meaning and Knowledge in the Making of Taiwanese Identity (Houndmills:

Palgrave Macmillan, 2007), 5-6.
} 
opposed to Chinese or a combination of both, and preferences regarding unification with the PRC, independence or maintenance of the present status quo. ${ }^{17}$ Many qualitative studies of Taiwanese nationalism focus on intellectuals, political elites, education or ethnic issues. A survey of recent academic history-writing points out an overemphasis on the origins of Taiwanese nationalism instead of contemporary identity formation, on literary writings and state categorisations in discussions of local identity. ${ }^{18}$ In contrast with "the hard empirical realities conjured by policy analysis and scholarship', Mark Harrison proposes the concept of 'story', implying creativity and invention, 'as a way of destabilising epistemological and institutional conditions that are specific to the way Taiwan is structured as an object of knowledge'. ${ }^{19} \mathrm{He}$ demonstrates that it is not only established epistemes as instruments of domination (Western, Chinese or partisan party politics) that contribute to shaping this knowledge, but also other stories involving materiality, social practices and bodies in motion, lived sensorial experience, emotions and memory. Although marginal, ephemeral, subjective and unsystematic, making 'no claims on narrative completeness' and not legitimised by traditional knowledge-makers, these stories are significant as they contest or complement dominant structures. ${ }^{20}$

Local accounts of Taiwanese nationhood have emphasised hybridity and multiculturalism since the late 1980s, when the concept of 'four major ethnic groups' emerged (Hoklo, Hakka,

${ }^{17}$ Shelley Rigger, Taiwan's Rising Nationalism: Generations, Politics and 'Taiwanese Nationalism'

(Washington: East-West Center, 2006); Frank Muyard, 'The formation of Taiwan's new national identity since the end of the 1990s', in Taiwan Since Martial Law: Society, Culture, Politics, Economy, ed. David Blundell (Taipei: National Taiwan University Press, 2012), 297-366; Jean-Pierre Cabestan, 'Changing identities in Taiwan under Ma Ying-jeou', in Taiwan and China. Fitful Embrace, ed. Lowell Dittmer (Oakland: University of California Press, 2017), 42-60.

${ }^{18}$ Evan Dawley, 'The question of identity in recent scholarship on the history of Taiwan', The China Quarterly 198 (June 2009): 442-52. This also applies to recent works, such as A-chin Hsiau, 'Jizhu Diaoyutai: lingtu zhengduan, minzuzhuyi, zhishi fenzi yu huaijiu de shidai jiyi' (Remember the Diaoyutai Islands: territorial dispute, nationalism and generational memory of nostalgic intellectuals in Taiwan), Taiwanshi yanjiu (Taiwan Historical Research) 24, 3 (2017): 141-208; A-chin Hsiau and Horng-luen Wang, eds, Zuqun minzu yu xiandai guojia. Jingyan yu lilun de fansi (Ethnicity, Nation, and the Modern State: Rethinking Theory and Experience in Taiwan and China) (Taipei: Institute of Sociology, Academia Sinica, 2016).

${ }^{19}$ Mark Harrison, 'Art, violence and memory in Taiwan: telling the story of the beautiful island', Thesis Eleven $146,1(2018), 5$.

${ }^{20}$ Harrison, 'Art, violence and memory in Taiwan', 16-17. 
Mainlanders and indigenous peoples). ${ }^{21}$ The year 2005 marked the heyday of the non-elite taike as the epitome of Taiwaneseness, 'a new culture, hybrid and inclusive' transcending local ethnicity, combining Chinese and Western elements into a kitschy 'bling-bling'-style popular aesthetics embodied in behavioural patterns and sartorial and other consumer choices. ${ }^{22}$ President Tsai Ing-wen's programme for the 2016 elections upheld a specifically Taiwanese culture, defined as hybrid, diverse or 'mix-and-match'. ${ }^{23}$ Transnational comparisons and relationality are also highlighted by recent scholarship. Attempting to update the relevance of Taiwan Studies as a discipline, Shu-mei Shih disentangles Taiwan from its Cold War ties with China. She moves beyond the Sinophone framework and describes Taiwan as a site of meaning already part of transnational networks and global processes: 'a node in the power-laden and interconnected world', a target for American cultural influences, destination and source for migration flows. ${ }^{24}$ Other scholars ${ }^{25}$ also reject essentialising perspectives on identity and history aimed at (re)affirming uniqueness and specificity, as well as 'forced, directed dialogues ${ }^{26}$ setting Taiwan against China or its Northeast Asian neighbours. Instead, they advocate novel comparative viewpoints and individualised, fluid forms of collective identity based on global connectivity.

In 2002, Allen Chun commented on the inward-looking character of Taiwan's multiculturalism postulated by advocates of indigenisation. As essentialist as the KMT Chinacentred project, this view of multiculturalism both othered China and ignored an increasing transnational flow of 'invisible others' - marriage migrants and contract labourers. ${ }^{27} \mathrm{He}$ deemed Taiwan a 'post-nation' successfully integrated into the transnational economy, enjoying international recognition as such despite decreasing recognition as a nation. While acknowledging the productivity of Shih's relational perspective on Taiwan, Michael Berry emphasises the island's deepening economic and cultural ties with China, despite efforts to

${ }^{21}$ Fu-chang Wang, Dangdai Taiwan shehui de zuqun xiangxiang (Ethnic Imagination in Contemporary Taiwan)

(Taipei: Qunxue, 2003).

${ }^{22}$ Zhongguo Shibao bianjibu (China Times Editorial Office), Taiwan guanjianzi: shi'er ge shehui xin dongli

(Taiwan Keywords: Twelve New Social Motive Forces) (Taipei: Tianxia yuanjian, 2013), 177-9.

${ }^{23}$ Further details are available at iing.tw (accessed 23 May 2019).

${ }^{24}$ Shu-mei Shih, 'Forum 2: linking Taiwan Studies with the world', 211-15.

${ }^{25}$ Bi-yu Chang and Pei-yin Lin, eds, Positioning Taiwan in a Global Context: Being and Becoming (Abingdon:

Routledge, 2019); Carsten Storm (ed.), Connecting Taiwan (Abingdon: Routledge, 2018).

${ }^{26}$ Frank Muyard, 'Comparativism and Taiwan Studies: analyzing Taiwan in/out of context, or Taiwan as an East Asian new world society', in Comparatizing Taiwan, eds Shu-mei Shih and Pinghui Liao (Abingdon:

Routledge, 2015), p. 18.

${ }^{27}$ Allen Chun, 'The coming crisis of multiculturalism'. 
politically distance itself from the PRC. He warns that ignoring such ties would only lead to haphazardly establishing new national myths. ${ }^{28}$

This study will shift the viewpoint away from the state, political and intellectual elites, towards a different kind of cultural producers and their Taiwan-related personal stories narrated through graphic novels and picture books. The unprecedented explosion of visual experiences in contemporary everyday life and the increasing role of commercial, popular culture in shaping people's worldview ${ }^{29}$ contribute to such texts' significance as research material. Comics have received increasing academic recognition for their valuable and innovative contribution to discussions and renegotiations of significant issues that include gender, ${ }^{30}$ historical trauma, ${ }^{31}$ practices of journalism, ${ }^{32}$ or national identity and cultural hybridity. ${ }^{33}$ The emergence of postmodern picture books and other major changes in the medium since the turn of the millennium have also received scholarly attention. ${ }^{34}$ However, comics and picture books remain largely unexplored by Taiwan's academia, a fact mostly due to enduring negative connotations with children's entertainment, still in place since the 1970s.

Comics in Taiwan developed under Japanese influence. During the martial law era (1947-87) topics related to Chinese history, mythology, martial arts or anti-Communist propaganda were dominant. ${ }^{35}$ Reflecting the broader wave of indigenisation, the 1990 s witnessed a surge in

${ }^{28}$ Shu-mei Shih, 'Forum 2: linking Taiwan Studies with the world', 223.

${ }^{29}$ Nicholas Mirzoeff, How to See the World. An Introduction to Images, from Self-Portrait to Selfies, Maps to Movies, and More (New York: Basic Books, 2016), 3.

${ }^{30}$ Hillary Chute, Graphic Women: Life Narrative and Contemporary Comics (New York: Columbia University Press, 2010).

${ }^{31}$ Marianne Hirsch, 'Family pictures: Maus, mourning, and post-memory', Discourse 15, 2 (1992-3): 3-29; Hillary Chute, “"The shadow of a past time": history and graphic representation in Maus', TwentiethCentury Literature 52, 2 (2006): 199-230.

${ }^{32}$ Daniel Worden, The Comics of Joe Sacco: Journalism in a Visual World (Jackson: University Press of Mississippi, 2015).

${ }^{33}$ Amy Malek, 'Memoir as Iranian exile cultural production: a case study of Marjane Satrapi’s Persepolis series', Iranian Studies 39, 3 (2006): 353-80; E. Dawson Varughese, Visuality and Identity in PostMillennial Indian Graphic Narratives (Houndmills: Palgrave Macmillan, 2018).

${ }^{34}$ Cherie Allan: Playing with Picturebooks. Postmodernism and the Postmodernesque (Houndmills: Palgrave Macmillan, 2012); Bettina Kümmerling-Meibauer, 'From baby books to picturebooks for adults: European picturebooks in the new millenium', Word \& Image 31, 3 (2015): 249-64.

${ }^{35}$ For a historical overview of comics in Taiwan, see John A. Lent, Asian Comics (Jackson: University Press of Mississippi, 2015), 97-115, and Yiyun Li, Manhua de wenhua yanjiu. Bianxing, xianghui yu fuhaohua de 
local themes - Taiwan's unique history, religion and social issues. Japanese comics still dominate the market, and the manga style continues to influence local works regardless of subject matter. Independent comics with idiosyncratic visual styles constitute a market niche relatively unknown in Taiwan but increasingly visible abroad. In 2009, individual Taiwanese artists began attending European events such as the Angoulême International Comics Festival. Their success caused state institutions to become aware of the potential of comics and picture books for public diplomacy. By 2018, this potential had gained full official recognition, ${ }^{36}$ with the Ministry of Culture leading several projects aimed at nurturing creativity and showcasing Taiwanese comics locally and internationally. Some publishers specialise in homegrown artists with individual styles. Among these is Dala, whose editor-inchief Aho Huang is committed to cultivating graphic novels (a category recently emerged in Taiwan) and to enhancing their international saleability in Europe. ${ }^{37}$

This study focuses on graphic narratives that break away from Japanese visual influences, explicitly address the idea of Taiwaneseness, result from collaborative projects with artists from other countries, and/or are internationally promoted by ROC government institutions. The sample includes the following works: two earlier autobiographical works by Sean Chuang and Youxiang Ao; ${ }^{38}$ Sean Chuang's recent graphic memoir included in the Ministry of Culture's promotional programme 'Books from Taiwan'; 39 a picture book by Soupy Tang, displayed by the same ministry at the 2017 Bologna Children's Books Fair; ${ }^{40}$ and two collections of short works by authors from Taiwan, Hong Kong and New Zealand published by Dala. ${ }^{41}$ Youxiang Ao is an older artist (born in 1956) who rose to fame in the 1980s with a series drawing upon the Chinese martial arts tradition; the book chosen here marks his turn towards Taiwan. Sean Chuang and Dala editor Aho Huang belong to a generation known as

xipu (Cultural Studies of Comics. Tracing Changes in Form, Image Symbolism and Semiotic Representation) (New Taipei: Daotian, 2012), 163-258.

${ }^{36}$ Ministry of Culture (MOC), Wenhua zhengce baipishu 2018 (Culture White Paper 2018), 131; available at the MOC website (https://www.moc.gov.tw/informationlist_302.html; accessed 25 May 2020).

${ }^{37}$ Personal interviews: October 2017, February 2020.

${ }^{38}$ Sean Chuang, Guanggaoren shouji (A Film Maker's Notes) (Taipei: Dala, 2013; first published in 1997); Youxiang Ao, Yi zhi jiaozuo Bianshi de mao (A Cat Called Dumpling) (Taipei: China Times Publishing, 2001).

${ }^{39}$ Sean Chuang, 80 niandai shijianbu (80s Diary in Taiwan) (Taipei: Dala, 2013).

${ }^{40}$ Soupy Tang, Genzhe Soupy fangsong, together (Relax with Soupy) (Taipei: Uni-Books, 2015).

${ }^{41}$ Seeman Ho et al., Taibei 80 X Xianggang 90 (80s Taipei X 90s Hong Kong) (Taipei: Dala, 2014); Sean Chuang et al., Daoyu liwu. Taiwan Niuxilan tuxiang xiaoshuo chuangzuoji (Island to Island. A Graphic Exchange between Taiwan and New Zealand) (Taipei: Dala, 2016). 
'fifth graders' (wunianji) in Taiwan, i.e. people born between 1961 and 1970 (the fifth decade since the establishment of the Republic of China). As with the American 1960s generation, the habitus of the Taiwanese 'fifth graders' was shaped by social movements and popular culture, ${ }^{42}$ a feature shared with the young 'naturally independent' generation born after the $1980 \mathrm{~s},{ }^{43}$ represented in the sample by Soupy Tang.

Given the unstable and contested character of Taiwanese identity-making, the individual, subjective engagement in identity politics is equally important as state or collective action. The authors discussed here contribute individual, lesser 'stories' (in Mark Harrison's terms) to the discourse of nationhood, while also proving that everyday performances thereof elude Taiwanese academics' desire to reify or pinpoint national identity. Multifaceted, affective and fundamentally grounded in an immediate material environment, such marginal narratives may incorporate or challenge dominant, elite accounts, thus building their own stances regarding Taiwan's relations with China, Japan and other regions, or the degree and configuration of cultural diversity underlying Taiwaneseness.

The study will adopt a viewpoint of discourse analysis, according to which discourses (interrelated texts and 'the practices of their production, dissemination and reception, ${ }^{44}$ ) shape social reality and inform social interaction. The chosen graphic narratives will be considered as texts (discourse units) and the following issues, as represented therein, will be considered: (1) processes of self-identification while travelling abroad for leisure, work and studies; (2) depictions of local culture centred on familiar spaces open to outside elements appropriated through daily activities which link them to individual emotions and weave them into personal and collective memories; (3) transnational encounters and connections that place Taiwan within a global or regional framework. The study will also assess to what extent Allen Chun's critique of Taiwan's multiculturalism and Michael Berry's warning against

${ }^{42}$ Ron Eyerman and Bryan S. Turner, 'Outline of a theory of generations', European Journal of Social Theory 1 , 1 (1998): 91-106. This fact was also signalled by Sean Chuang in an interview the author conducted in May 2017.

${ }^{43}$ For a definition of the Taiwanese 'naturally independent' generation, see Chih-jou Jay Chen, 'Economic interests or national sovereignty. Public opinion on the cross-strait dilemma during the Ma Ying-jiu era', in Assessing the Presidency of Ma Ying-jiu in Taiwan. Hopeful Beginning, Hopeless End?, eds André Beckershoff and Gunter Schubert (Abingdon: Routledge, 2018), 111-13.

${ }^{44}$ Nelson Phillips and Cynthia Hardy, Discourse Analysis. Investigating Processes of Social Construction (London: Sage Publications, 2002), 3. 
overlooking cross-strait ties in contemporary definitions of nationhood may hold true for the analysed texts.

\section{Travelling Subjects}

James Clifford points out the importance of travel and cosmopolitan encounters in constituting cultural experience, negotiating homes and identities. ${ }^{45}$ Paul Jones and Michał Krzyżanowski speak of discovered identity caused by dislocation from the place of origin, and of patterns of belonging dynamically constructed in relation to both the original and the new social settings. ${ }^{46}$ Studies of Taiwanese cinema emphasise round-the-island journeys as bodily experiences building awareness of a local identity linked to Taiwan's geographical scope as a nation. ${ }^{47}$ In the graphic narratives analysed here, it is overseas travel that plays this role. Their narrators are gazing at other cultures during everyday performances as temporary residents: tourists, foreign students or professionals on business trips. This activity reveals cultural differences and causes the persons involved to play out their own cultural identity. Their outsider's gaze thus works as 'a performance that orders, shapes and classifies, rather than reflects the world ${ }^{48}$ for the reader.

China is featured in Ao and Chuang's travelogues. Ao records his travels to the PRC and Hong Kong, where he attends comics symposiums, both destinations providing occasions for intercultural comparison. ${ }^{49}$ These two accounts are built upon parallel themes but also differ in significant respects. Both travelogues position the narrator as a tourist whose gaze is shaped by established conventions instead of the actual perceived environment. China and its people are represented as pandas, and Beijing's climate as exceedingly cold. While Hong Kong is depicted as a consumer's heaven, China is branded by its Communist heritage. Upon arrival in China, the narrator is greeted by a young couple reminiscent of traditional new year prints revamped as propaganda posters - a boy and a girl wearing Maoist suits and caps.

\footnotetext{
${ }^{45}$ James Clifford, Routes. Travel and Translation in the Late Twentieth Century (Cambridge, MA: Harvard University Press, 1997), 24-6.

${ }^{46}$ Paul Jones and Michał Krzyżanowski, 'Identity, belonging and migration: beyond constructing "others"', in Identity, Belonging and Migration, ed. Gerard Delanty (Liverpool: Liverpool University Press, 2008), 39, 46.

${ }^{47}$ For an overview, see Ssu-fang Liu Jessie, 'From visual discoveries to bodily trajectories: the insular epistemology of around-the-island journeys in Taiwan cinema', East Asian Journal of Popular Culture 3, 2 (2017): 199-213.

${ }^{48}$ John Urry and Jonas Larsen, The Tourist Gaze 3.0 (Los Angeles: Sage Publications, 2011), 2.

${ }^{49}$ Ao, Yizhi jiaozuo Bianshi de mao, 45-53, 77-85.
} 
Both chapters depict bodies in motion, but freedom of movement varies. Direct flights connect Hong Kong to Taiwan, and a comparison of local transportation reveals its superiority over Taiwan. The chapter on China highlights obstacles hindering movement, with a compulsory stopover in Hong Kong or Macao and a long queue at the PRC border for ROC citizens. While the terms 'little sister' and 'elder brother' used for Hong Kong and Taiwan imply close bonds, China is othered through various strategies. The term Taibao ('Taiwan compatriots'), used in the official PRC discourse, is adopted in the chapter but is subverted with a linguistic and visual pun. The Taiwanese queuing at the border are drawn from a Chinese perspective that is othering and uniformising, with steamed buns as their heads, and PRC citizens they encounter label them 'slow-witted steamed buns' (dai bao). Ao positions his persona as a tourist directing an outsider's gaze at historical sites that embody a past not appropriated as his own. The travelogue's last two pages feature the Chinese panda and Taiwanese wild boar facing each other with fierce expressions, and Ao standing behind the Great Wall, which cuts off the Taiwan he calls 'home' from a PRC thus presented as a separate entity.

Chuang's account of his trip to $\mathrm{China}^{50}$ is noteworthy for the strategies of national identification adopted by his persona and his positioning of characters, which differs according to their origins. The chapter tells a story of regional cooperation in producing a video advertising a Japanese noodle brand. The ad is commissioned by Dentsu (a well-known Tokyo-based advertising and PR company) to the narrator's Taiwanese employer, the two triggering the narrator's reminiscences of colonial domination and national self-identification as Chinese. Interestingly, his object of identification is not the actual, contemporary China, but cultural constructs originating outside the PRC. When expressing anti-Japanese sentiments, Chuang draws himself as characters from Hong Kong films set in Qing China: a 1992 comedy starring Stephen Chow as a Confucian official, and the legendary 'Sick Man of Asia' scene in Bruce Lee's Fist of Fury. He also borrows the martial law era KMT antiimperialist discourse of 'Japanese devils' and 'national enmity'. The China that Dentsu wishes to represent is imagined from a Japanese viewpoint: the ad is set in imperial China and shot in Beijing, but its Taiwanese producers are required to cater to Japanese tastes.

The collaboration involves a team composed of Taiwanese, Hong Kongers and Chinese, but traits such as global mobility, economic and decision-making power or professional knowhow are only attributed to the former. The PRC team acts as a mere subcontractor arranging the local settings and background actors - 300 soldiers of the People's Liberation Army (PLA), a key PRC institution derisively disempowered and shown as materially motivated in

\footnotetext{
${ }^{50}$ Chuang, Guanggaoren shouji, 245-85.
} 
Chuang's work. The soldiers provide commercial services to the Taiwanese and Hong Kong producers (self-identified as 'a bunch of foreigners' while in China). They eschew bothersome tasks (standing in the rain) but eagerly claim the money. The ad is shot on the PLA's founding anniversary, and the large group of soldiers are ordered by the bossy female co-director to strip in public and change into historical costumes. The production team is interested in China's (inauthentic) past, and images of contemporary Beijing do not appear modern. The city is repeatedly described as grey and dusty, and the drawings show people on bicycles, others sitting on low stools in the street, and low-rise dwelling compounds. In this way, Chuang's portrayal of China runs counter to the PRC's struggle for global modernity since the 1980s, denying it this achievement.

While China is denied participation in global modernity, Chuang's accounts of journeys to Europe (Spain, Greece, Paris, Vienna) ${ }^{51}$ portray Taiwanese characters as savvy cosmopolitans. They spend holidays abroad and are proficient in organising such trips knowledgeable about related formalities (visas, hotel reservations) and possible inconveniences (insufficient space on planes). They are economically empowered as consumers with middle-class-level incomes who can afford trips to Europe, where they go shopping, eat at restaurants and give money to beggars. These chapters also show Taiwan as a developed country where diverse goods are readily available: flight tickets, suitcases and backpacks of all sizes (one chapter offers a crash course in travelling light). The Taiwanese enjoy freedom of independent transnational movement: their trips are self-organised, and the narrator often explores foreign countries alone. All these features attributed to Taiwan implicitly contrast it with China, where such possibilities were still limited during the 1990s. At the same time, the descriptions of foreign lifestyles and spaces seen from a Taiwanese perspective highlight an awareness of cultural differences. Being Taiwanese is expressed in favourite pastimes while abroad (eating, searching for famous restaurants) and social networking with expat compatriots acting as local guides.

The narrator is portrayed not only as a seasoned traveller, but also as already acquainted with the countries being visited. Earlier knowledge of European art and everyday life motivates his choice of travel destinations, and while abroad he compares previous mental images with actual places he has visited. Much emphasis is placed on his long duration of exposure to Western cultures while still in Taiwan, and the significant formative effects they had on his artistic vision. His trip to Spain is motivated by fascination with Gaudi's architecture (seen in Taiwanese travel magazines) and with Dali's works, a fascination dating back to secondary school when he would share such interests and exchange information with family and friends.

\footnotetext{
${ }^{51}$ Chuang, Guanggaoren shouji.
} 
This implies that European culture shaped not only the narrator as an individual artist but his whole generation, through immersion in a globalised media system and free peer-to-peer exchange.

Soupy Tang's picture book is designed as a comparison between Taiwan and the UK performed by the author as self-styled ethnographer. She focuses on the topic of relaxation through everyday pastimes which embody a specific, local lifestyle and express cultural differences. She documents her own observations while studying in Edinburgh, in drawings and handwritten texts that reveal the process of discovering a Taiwanese cultural identity while living abroad. Her 'research report' resembles a sketchbook with spontaneous, somewhat chaotic jottings testifying to much attention paid to minute, intimate details, sensorial experiences and emotions related to home, its immediate surroundings, bodily performance and everyday social interaction. Britishness and Taiwaneseness are defined through mundane material objects and activities - local fruits and vegetables, kitchen utensils, bathroom appliances, shopping in stores, at car boot sales and night markets; professional uniforms and sartorial choices, cooking recipes; practices of bathing, walking dogs, going to parks or pubs. National identity is thus continuously reproduced and lies in the particulars of ordinary people's everyday performances. Relaxation is a type of practice common to people all over the world, but it is the specificity of 'how we do things' that defines one's national belonging.

\section{Taiwan's Hybridity}

According to Doreen Massey, the identity of a place is determined by 'the juxtaposition and co-presence there of particular sets of social interrelations, and by the effects which their juxtaposition and co-presence produce'. Such identities are not stable and bounded, but dynamic and 'in part constructed out of positive interrelations with elsewhere'. ${ }^{52}$ A sense of place that she deems problematic is built upon belief in single, essentialised identities, an inward-looking history, boundaries and single, coherent communities. To this notion Massey opposes the progressive idea of a 'meeting place' or 'constellation of social relations, meeting and weaving together at a particular locus'. ${ }^{53}$ This extroverted, processual sense of place implies a multitude of coexisting, competing identities and an awareness of linkages both local and wider, creating a layered, accumulated history. Edensor also shows that the lifestyles of specific national communities are constructed over time through social and cultural relations, embedded in local institutional infrastructures and influenced by global

\footnotetext{
52 Doreen Massey, Space, Place and Gender (Minneapolis: University of Minnesota Press, 2001), 168-9.

${ }^{53}$ Massey, Space, Place and Gender, 154.
} 
flows. The symbolic meanings of local products evolve, and foreign commodities are domesticated, acquiring nationally relevant symbolic values. ${ }^{54}$

Sean Chuang's works underscore Taiwan's cultural hybridity, displaying a salient awareness of rooting imported elements in local conditions. His Guanggaoren shouji (hereafter 'Film Maker's Notes') includes a chapter on cinema-going. ${ }^{55}$ Giuseppe Tornatore's film Nuovo Cinema Paradiso, watched in his late teens with his father in Taichung, serves as a pretext for reminiscing on earlier experiences. Chuang's chapter parallels the Italian movie's plot, showing the formative role of cinema for his career as video ad director. However, it is not only films themselves that have played this role, but the entire movie-going experience with all its aspects: global and local connections, the senses and emotions. Chuang depicts cinemagoing as a means for emotional bonding with his father. This experience also involves sensorial immersion in a Taiwanese environment with all its specificities (such as the climate). Chuang's description of the Taichung cinema (subsequently demolished, and thus sharing the fate of Cinema Paradiso) repeatedly appeals to the senses: the humidity, the unpleasant smell from air-con machines, out-of-focus images on the screen, malfunctioning loudspeakers. His drawings of the cinema and spectators provide a detailed account of local everyday life, recurrent across Taiwan: food stalls, children eating snacks and casually dressed movie-goers.

The idea of Europe's formative role in shaping artistic vision is also inherent in Ahn Zhe's works included in one of the Dala collections, intended as presents to collaborating New Zealand artists. His photographs resulted from personal observation: 'I've recorded the places and sights I see regularly, to share with you the common scenery of my everyday life. ${ }^{56}$ Although photographed in Taipei, such mundane spaces, objects and people are ubiquitous throughout Taiwan: small restaurants, low-rise apartment buildings with metal bars in the windows, water tanks and illegal extensions on roofs, electric cables hanging above streets, scooters, wicker baskets, construction workers and old-fashioned barber shops. These sights are recognisable as specifically Taiwanese and thus reproduce a sense of national identity as local lifestyle in Edensor's terms. At the same time, Ahn's photos constitute a reflection on the history of the medium. By their colour scheme (black and white), their graininess, dark areas around the frames and resemblance to negatives, they call to mind daguerreotypes and the beginnings of photography. This association is reinforced by the photos being printed on

\footnotetext{
${ }^{54}$ Tim Edensor, 'Automobility and national identity: representation, geography and driving practice', Theory Culture Society 1, 1 (2004): 102-3, 106.

55 Chuang, Guanggaoren shouji, 168-74.

${ }^{56}$ Chuang et al., Daoyu liwu, 46.
} 
old paper inscribed in French. Therefore, while stating his Taiwaneseness through the content of his photographs, Anh also relates to a global heritage - the history of photography.

Chuang's graphic memoir ${ }^{57}$ depicts contemporary Taiwan as the meeting point of global, regional and local factors and identities that emerged, increased or decreased in significance, and lost their initial cultural connotations or acquired new ones at different times and in different social contexts. He constructs an idea of national history as a configuration of fragments of diverse origins, a history democratically and readily available through everyday experiences involving its extant material and cultural vestiges. ${ }^{58}$ Imported from colonial Japan, baseball became a stake in Taiwan's struggle for international recognition during the early 1970s. Bruce Lee's wildly popular films reinforced the Chinese identity upheld by the KMT authoritarian government at an everyday level, but their nationalist message became eroded when incorporated into Taiwanese viewers' everyday practices. An old mainland Chinese soldier is initially represented as a black silhouette, an 'ape-man' speaking in an unintelligible tongue, who chases children away from his fields. Hurling rocks at him, the children re-enact the post-1949 trauma of the Mainlander Taiwanese, for which they receive their teacher's reprimand. At the end of the chapter, the identity of the scary, mysterious 'apeman' is disclosed in images that integrate Mainlanders into Taiwanese society and show their positive contribution thereto.

Apart from these regional influences, Chuang's memoir also elaborates on Taiwan's American and European connections. A chapter on breakdancing ${ }^{59}$ begins with an allusion to neocolonial history and the preoccupation with American culture as paradoxical core of Taiwanese collective memory. ${ }^{60}$ Chuang mentions breakdancing's New York origins and positions Taiwan as immersed in global media culture by mentioning Joel Silberg's 1984 film Breakin', which made him aware of this genre. Simultaneously, Chuang shows that 'globality is also an endocentric, selective process of assimilation': ${ }^{61}$ some of breakdancing's initial connotations were lost or reshaped to suit local conditions. African American hip-hop culture had its roots in the civil rights movement and was intended as a form of social critique against poverty, drugs, prejudice or discrimination, coming from an underprivileged group

\footnotetext{
${ }^{57}$ Chuang, 80 niandai shijianbu.

58 For a detailed account of this idea of history, see Adina Zemanek, 'National history and generational memory

- Taiwanese comic books as lieux de mémoire, positions: asia critique, 28, 2 (2020), 389-420.

${ }^{59}$ Chuang, 80 niandai shijianbu, 141-53.

${ }^{60}$ Emilie Yueh-Yu Yeh, 'Elvis, allow me to introduce myself: American music and neocolonialism in Taiwan cinema', Modern Chinese Literature and Culture 15 (Spring 2003): 5.

${ }^{61}$ Yeh, 'Elvis, allow me to introduce myself'.
} 
and targeting a similar youth audience. ${ }^{62}$ In the process of becoming a part of Taiwanese youth culture as depicted by Chuang, breakdancing remained a display of male physical prowess through street performance. However, its links to race, rapping and disadvantaged groups were lost. Instead, Chuang shows breakdancing transformed into other forms of resistance, albeit less explicit and confrontational, deeply embedded within the martial law regime and Taiwan's 'economic miracle', and embodying the subtle relationships between official discourse and youth culture.

Promoted by state-controlled television that encouraged copying of American idols, and made popular by readily available cassette and VHD players, breakdancing was taken over by young Taiwanese on their own terms. It gave rise to a participatory spirit of community among practising youths, also connecting them with the viewers of their ad-hoc street performances, depicted as people of various ages and from all walks of life. Breakdancing also allowed the narrator to overcome shyness and gain a sense of personal achievement, and integrated youth communities under a repressive educational system involving surveillance, uniformity and bodily conformity. Young Chuang and his friends use whatever means available to turn compulsory short hairstyles into fashionable looks at the discos. Schoolboys practise breakdance movements on breaks, despite admonitions from the school's military officer. Dancing is also presented as a means of defiance under martial law, when discos were banned but emerged underground. It also reflects local cultural hierarchies: Taiwanese official media's subservience to US models, and a standing opposition between north and south. Chuang's story shows northern Taipei as cultural centre: his young persona learns new dance movements in Taipei and teaches them to awe-struck friends in his southern home town of Taichung. The end of the chapter highlights the lasting effects this 1980s-90s trend had on Taiwanese youth culture: the grown-up narrator is shown passing a group of present-day street dancers practising with a trainer.

European connections are established in the chapter dedicated to Vespa scooters. ${ }^{63}$ Dick Hebdige $^{64}$ speaks of the 'cultural significance' of material objects - the symbolic meanings, values and functions accumulating over time, different for users situated in varied geographical, cultural and temporal localities. Designed in the 1940s as an inexpensive, attractive and convenient means of transportation, the Italian Vespa's marketing strategy consisted in associations with modernity, style and femininity. Upon introduction to the UK

\footnotetext{
${ }^{62}$ Derrick P. Alridge, 'From civil rights to hip hop: toward a nexus of ideas', The Journal of African American History 90 (Summer 2005): 226-52.

${ }^{63}$ Chuang, 80 niandai shijianbu, pp. 155-65.

${ }^{64}$ Dick Hebdige, 'Object and image: the Italian scooter cycle', in Dick Hebdige, Hiding in the Light: On Images and Things (London: Routledge, 1988), 77-115.
} 
in the 1950s, the Vespa was relocated into the British sports tradition, which erased its undertone of effeminacy. Its original connotations with fashion and elegance gained significance from the mid-1960s when the Vespa became associated with Londoner 'mods' and their self-image involving sartorial refinement and aestheticisation of everyday life.

Chuang's chapter begins with stating the role motorcycles played in Taiwanese public performances of manliness and in creating a masculine community of insiders to technical jargon. He then introduces the Vespa in a context humorously contrasted with its European connotations, while also deeply interlinked with a local, non-elite culture. His teenage persona is portrayed as lacking economic power and conventional masculinity. While his classmates ride their own motorcycles, commanding admiring female gazes, Chuang only borrows the less-than-masculine Vespa and is unable to master it. The unruly Vespa dashes past a row of parked scooters, overturns them, nearly crashes into a bus, makes a quick dodge, hits a betel stand and collapses at the feet of the angry stand owner. The blue-andwhite plastic slippers donned by Chuang and the practice of betelnut chewing are stereotypical markers of the taike culture promoted as connoting Taiwaneseness since the 1990s. Ridden by a young Taiwanese who bumps into betel stands, the Vespa is depicted as little more than an ordinary scooter (yet another marker of the taike), thus moving away from Western-style modern refinement and becoming incorporated into a local symbolic order.

\section{Taiwan's Transnational Connections}

Brubaker and Cooper ${ }^{65}$ replace the reified, axiomatic concept of identity with the active, processual idea of identification by the self and by others. Chang and Lin adopt a similar approach, speaking of 'feedback loops and continuous interplays' ${ }^{66}$ between local and external viewpoints that constitute Taiwan's culture and identity amid global cultural flows. Dala Publishing's collaborative projects involving Taiwanese and foreign artists from New Zealand and Hong Kong display keen interest in placing Taiwan within relational contexts that reveal novel perspectives on the island as perceived by others. Several works in these collections exploit the motif of mutual gazing and bonds across space to underscore Taiwan's global connectedness and regional position, and the multitude of concurrent perspectives (local, external and comparative) that contribute to articulating it as a sign.

In the New Zealand book, Tim Gibson ${ }^{67}$ superimposes the personal over the national through

\footnotetext{
${ }^{65}$ Brubaker and Cooper, 'Beyond "identity", 15.

${ }^{66}$ Chang and Lin, Positioning Taiwan, 3.

${ }^{67}$ Chuang et al., Daoyu liwu, 23-9.
} 
an analogy between the development of artistic creativity and the emergence of New Zealand's national bird, the kiwi. The kiwi's peculiarity is attributed to characteristics of its natural habitat. The idea of creativity is visually rendered as New Zealand's map, and the factors determining and limiting it (family expectations, existing works and established concepts of art, new media, national policies, history, etc.) are drawn as pieces of continent surrounding the islands. New Zealand's insularity, the kiwi's uniqueness and the universality of Gibson's message make it easily applicable to Taiwan and its peculiar international situation. Rae Joyce ${ }^{68}$ depicts Taiwan as globally tuned in through worldwide distribution of media reports concerning the island. She also underscores the organic interconnectedness of Taiwan with the world in terms of global ecological balance: environmental pollutants will affect remote geographic locations, far away from their initial sources.

Joyce also gives an interesting account of China and its relationship to Taiwan. ${ }^{69}$ In a chapter intended as a present for Taiwanese artist Sean Chuang, she explores the motifs of mutual connections, gazes, artistic influences and reinterpretations of the past. The shape of a pot Joyce made at the age of seventeen is employed as a frame that links together images from her own history as a ceramicist and scenes from a visit to the National Palace Museum in Taipei with Chuang as a guide. Joyce's translation of a material artefact produced in the past into a contemporary visual image is paralleled by images of Chuang's reinterpretation of Chinese history. During their museum visit, Joyce and Chuang gaze at the same exhibits but frame them differently. Rae chooses faithful representation, thus taking over the role of guide to China's history initially attributed to Sean. She sketches the porcelain objects she sees and takes notes on their names in Chinese, the period when they were produced, production techniques, purposes they served, etc. Sean chooses a different approach that disconnects these artefacts from their status as vestiges of the past. He deconstructs the China-centred historical narrative and redirects Rae's gaze towards Taiwan. He considers only the exhibits' appearance, which he reinterprets from a personal perspective, thus refusing to adopt China's past as his own. He refers to two Qing-era conjoint porcelain vases by a newly coined name 'butt vase'. This label constitutes a carnivalising strategy that denies the vases' initial status of high culture and prized collectors' items, thus bringing them into the realm of bawdy humour. A Han dynasty funerary figurine representing a pig is reinterpreted by Sean as a wild boar, which may constitute an allusion to the Formosan wild boar, often used as an emblem of Taiwan. He shows Rae photos of a similar figurine taken during his trip to Paris, thus connecting to Europe instead of China through a skilful detour that subverts established frameworks of reference.

\footnotetext{
${ }^{68}$ Chuang et al., Daoyu liwu, 38-45.

${ }^{69}$ Chuang et al., Daoyu liwu, 174-83.
} 
A story by Hong Kong artist Justin Wong included in the other collection ${ }^{70}$ has a marked political undertone related to Wong's career as a political cartoonist for Ming Pao Daily News, a Hong Kong newspaper committed to objectivity, liberalism and investigative reporting. The narrative is set in 2014 but alludes to the former British colony's handover to the PRC in 1997 and its contemporary political situation, in tune with the book's theme of the 1990s in Hong Kong. Wong's narrative highlights media and electronic communication, which can be used as an instrument for both transnational connectivity between Hong Kong and Taiwan and political dissent within Hong Kong. Political uncertainty in Hong Kong is rendered through images of a TV screen with news reports on protests. The dates displayed on the news stills are 1 July 2013 and 1 July 2014; 1 July was the day when Hong Kong became a Special Administrative Region of the PRC, a date commemorated with protests every year. Wong contrasts the choices made by two generations: a dissatisfied but inactive old father and his son, a young newspaper columnist with writer's block (an allusion to decreasing media freedom in Hong Kong). The latter is disillusioned with local politicians and increasingly estranged from his home town, where he refuses to settle down. He keeps in touch with friends in Taiwan via instant messaging and listens to Taiwanese popular music. Wong's story features a song by Zhang Xuan, known for her public support of the Anti-Media Monopoly Movement, the Sunflower Movement and Hong Kong's Umbrella Movement. The quoted lyrics are relevant for both the story's protagonist and Hong Kong itself: 'He sometimes falters but cannot decide which direction to take/The land in the legend may turn out to be nothing but sand/Anyhow, it's all right. The other shore is still a magic place.' The story ends with the son's decision to leave for Taiwan. The last panel contrasts the TV news presenter's 'devout prayers for tomorrow', which are bound to remain unanswered in Hong Kong, with 'a better tomorrow' (another allusion to a Taiwanese song) that the protagonist hopes to find in Taiwan.

\section{Conclusion}

Carsten Storm ${ }^{71}$ contrasts the ideology-driven, identity-centred academic narratives of Taiwan Studies, dominated by the theme of isolation, with actual practices of non-national entities (individuals, businesses, organisations), marked by a high degree of global connectedness and transnational participation. Consequently, he calls for shifting the analytical perspective from an abstract, fixed notion of Taiwaneseness towards individual experiences of engaging with the world, which engender fluid forms of identification. This

\footnotetext{
${ }^{70}$ Seeman Ho et al., Taibei 80 X Xianggang 90, 82-95.

${ }^{71}$ Storm, ed., Connecting Taiwan, 2-3, 34-5.
} 
study is an attempt at such a shift. Markedly mundane and non-elite, with a strong foothold in contemporary practice, the definitions of Taiwan articulated in the analysed graphic narratives do not aspire to pinpoint an ever-elusive uniqueness. Instead, they display Taiwaneseness as a dynamic 'cultural matrix"72 whose singularity arises from the current configuration of a constantly negotiated syncretism. They highlight Taiwan's past and present connections with other regions, and therefore the island's global integration rather than its marginalisation and vulnerability.

These representations of Taiwan conform to Doreen Massey's definition of a progressive, global sense of place. The island is depicted as open to transnational contacts and outside influences (Japanese, European, American or mainland Chinese after World War II) that have contributed to building its layered history. The cultural hybridity defining Taiwan in these texts does not seem to come hand-in-hand with an attempt at essentialisation and boundarydrawing present in other cases such as that of Trinidad, ${ }^{73}$ where historically constituted racial hybridity was revalued into purity and homogeneity as it became a key ideological component of what may have appeared to be an inclusivist nationalist narrative. This open acknowledgement of Taiwan's cultural diversity is, I believe, particularly significant given the recent surge of parochialism in many regions across the world.

Insofar as the analysed works highlight cultural diversity, interconnectedness and inclusivity, they may be said to present Taiwan as a 'post-nation' (to borrow Allen Chun's term), with a self-reflexive awareness that any essentialist claim is but an ideological construct.

Nevertheless, what these graphic stories highlight is cultural hybridity, not multiculturalism, which proves that Chun's critical view expressed in 2002 still holds valid. The 'others' whom Taiwan's earlier narrative of multiculturalism had failed to include, according to Chun, are now referred to in the media and academic discourse as the 'fifth ethnic group' of the island's national community. ${ }^{74}$ The graphic novels discussed underscore place, everyday life, material objects, practices and patterns of social interaction rather than categories of people (the only exception being the old Mainlander soldier). This may constitute an integrative strategy for bypassing old ethnic divisions between Mainlanders and native Taiwanese still salient in the 1980s and early 1990s, the period depicted in Sean Chuang's memoirs. But despite the

\footnotetext{
72 Edensor, National Identity, 17.

${ }^{73}$ Viranjini Munasinghe, 'Nationalism in hybrid spaces: the production of impurity out of purity', American Ethnologist 29 (August 2002): 663-92.

74 Todd L. Sandel and Chung-hui Liang, 'Taiwan's fifth ethnic group: a study of the acculturation and cultural fusion of women who have married into families in Taiwan', Journal of International and Intercultural Communication 3 (August 2010): 253.
} 
centrality of hybridity underlying Taiwan's recent history, neither Chuang's memoirs nor the remaining works in the sample (nor, for that matter, other comics the author has come across) account for the multiculturalism of contemporary Taiwan. This may reflect the time lag needed for comics as popular entertainment to catch up with social change, but also a deeprooted need to look (farther) back in narrative attempts at making meaning of personal and national experience.

The selected comics actively engage in renegotiating more established relational views (such as those including China, Japan or the US) while also situating Taiwan within other frames of reference that link it with Europe, Hong Kong or New Zealand. Some of the analysed texts focus on relations with regions other than China. Soupy Tang's 'homemade ethnography' does not mention China at all: it aims at defining a Taiwanese lifestyle distinct from the British one. Sean Chuang's 'Film Maker's Notes' depicts Taiwanese characters as seasoned international travellers well versed in European cultures. Both Chuang and Ahn Zhe construct their artistic identities through links with Europe. Dala Publishing's collaborative projects look towards Hong Kong and New Zealand as frameworks of comparison. However, rather than having become irrelevant for Taiwan's self-identification, China seems to maintain its significance as negative point of reference. Chuang's globally mobile, worldly-wise Taiwanese characters featured in his European travelogues contrast with the Chinese production team, confined to their home location in the chapter on the video advertisement. Rae Joyce's work shows Chuang turning towards France while rejecting China in his reinterpretation of National Palace Museum exhibits. Justin Wong's narrative also leaves behind a native Hong Kong negatively altered after the 1997 handover to the PRC, while embracing Taiwan as a desired 'other shore' and (implicitly) a haven of democracy.

Placing Taiwan in a transnational framework of reference that includes Hong Kong and New Zealand echoes the recent academic trend embodied in Shu-mei Shih's article, stating the need to approach Taiwan Studies through the lens of global relationality rather than from within an already outdated Sinophone paradigm. However, the texts analysed also seem to confirm Michael Berry's concern about the likelihood of creating new national myths instead of a new approach to China that would account for the PRC's contemporary economic and political situation, as well as for the recent evolution of cross-strait ties. When present in these texts, China is denied a position in global modernity, as in Chuang's chapter on the Japan-commissioned ad, or is conspicuously othered: Ao's travelogue draws a physical line dividing Taiwan from the PRC in the image of himself gazing towards the latter from behind the Great Wall. The China that Chuang's persona identifies with in his 'Film Maker's Notes' is not the actual PRC, but the national myth upheld by the KMT government during the martial law era. The eagerness to gain knowledge about Europe (in both the sense of artistic 
heritage and contemporary practices) reflected in Chuang's travelogues is paralleled by a lack of interest in knowing and representing contemporary China. Both Chuang and Ao depict it through a series of stereotypes popularised by martial law state propaganda and the school education these two authors received as part of their generational habitus. Nevertheless, the lack of China in the works of younger authors would still support Michael Berry's argument, regardless of whether this lack constitutes a structuring absence (in Chris Berry's terms), or a final escape from the limitations of a framework of reference that has become obsolete.

\section{References}

Allan, Cherie. Playing with Picturebooks. Postmodernism and the Postmodernesque (Houndmills: Palgrave Macmillan, 2012).

Alridge, Derrick P. 'From civil rights to hip hop: toward a nexus of ideas'. The Journal of African American History 90 (Summer 2005): 226-52.

Ao, Youxiang. Yi zhi jiaozuo Bianshi de mao (A Cat Called Dumpling) (Taipei: China Times Publishing, 2001).

Berry, Chris. 'Imagine there's no China. Wei Te-Sheng and Taiwan's “Japan Complex"'. In Taiwan Cinema: International Reception and Social Change. Edited by Kuei-fen Chiu, Mingyeh T. Rawnsley and Gary D. Rawnsley (Abingdon: Routledge, 2018).

Billig, Michael. Banal Nationalism (London: Sage Publications, 1995).

Bonikowski, Bart. 'Nationalism in settled times'. Annual Review of Sociology 42 (2016): 427-49.

Brubaker, Rogers, and Frederick Cooper. 'Beyond "identity"'. Theory and Society 29 (2000): $1-47$.

Cabestan, Jean-Pierre. 'Changing identities in Taiwan under Ma Ying-jeou'. In Taiwan and China. Fitful Embrace. Edited by Lowell Dittmer (Oakland: University of California Press, 2017).

Chang, Bi-yu, and Pei-yin Lin, eds. Positioning Taiwan in a Global Context: Being and Becoming (Abingdon: Routledge, 2019).

Chen, Chih-jou Jay. 'Economic interests or national sovereignty. Public opinion on the crossstrait dilemma during the Ma Ying-jiu era'. In Assessing the Presidency of Ma Ying-jiu in Taiwan. Hopeful Beginning, Hopeless End? Edited by André Beckershoff and Gunter Schubert (Abingdon: Routledge, 2018).

Chuang, Sean. 80 niandai shijianbu (80s Diary in Taiwan) (Taipei: Dala, 2013).

Chuang, Sean. Guanggaoren shouji (A Film Maker's Notes) (Taipei: Dala, 2013).

Chuang, Sean et al. Daoyu liwu. Taiwan Niuxilan tuxiang xiaoshuo chuangzuoji (Island to Island. A Graphic Exchange between Taiwan and New Zealand) (Taipei: Dala, 2016). Chun, Allen. 'The coming crisis of multiculturalism in "transnational" Taiwan'. Social Analysis 46, 2 (Summer 2002): 102-22. 
Chute, Hillary. "The shadow of a past time": history and graphic representation in Maus'. Twentieth-Century Literature 52, 2 (2006): 199-230.

Chute, Hillary. Graphic Women: Life Narrative and Contemporary Comics (New York:

Columbia University Press, 2010).

Clifford, James. Routes. Travel and Translation in the Late Twentieth Century (Cambridge, MA: Harvard University Press, 1997).

Dawley, Evan. 'The question of identity in recent scholarship on the history of Taiwan'. The China Quarterly 198 (June 2009): 442-52.

Edensor, Tim. National Identity, Popular Culture and Everyday Life (London: Berg, 2002).

Edensor, Tim. 'Automobility and national identity: representation, geography and driving practice'. Theory Culture Society 1, 1 (2004): 101-20.

Edensor, Tim, and Shanti Sumartojo. 'Geographies of everyday nationhood: experiencing multiculturalism in Melbourne'. Nations and Nationalism 24, 3 (2018): 553-78.

Eyerman, Ron, and Bryan S. Turner. 'Outline of a theory of generations'. European Journal of Social Theory 1, 1 (1998): 91-106.

Fox, John, and Maarten van Ginderachter. 'Introduction: everyday nationalism's evidence problem'. Nations and Nationalism 24, 3 (2018): 546-52.

Hall, Stuart. 'Introduction: who needs identity?' In Questions of Cultural Identity. Edited by Stuart Hall and Paul du Gay (London: Sage Publications, 1996), 4, 6.

Harrison, Mark. Legitimacy, Meaning and Knowledge in the Making of Taiwanese Identity (London: Palgrave Macmillan, 2007), 5-6.

Harrison, Mark. 'Art, violence and memory in Taiwan: telling the story of the beautiful island'. Thesis Eleven 146, 1 (2018): 3-23.

Hearn, Jonathan, and Marco Antonsich. 'Theoretical and methodological considerations for the study of banal and everyday nationalism'. Nations and Nationalism 24, 3 (2018): 594605.

Hebdige, Dick. 'Object and image: the Italian scooter cycle'. In Hiding in the Light: On Images and Things (London: Routledge, 1988).

Hirsch, Marianne. 'Family pictures: Maus, mourning, and post-memory'. Discourse 15, 2 (1992-3): 3-29.

Ho, Seeman, et al., Taibei 80 X Xianggang 90 (80s Taipei X 90s Hong Kong) (Taipei: Dala, 2014).

Hsiau, A-chin, 'Jizhu Diaoyutai: lingtu zhengduan, minzuzhuyi, zhishi fenzi yu huaijiu de shidai jiyi' (Remember Diaoyutai Islands: territorial dispute, nationalism and generational memory of nostalgic intellectuals in Taiwan). Taiwanshi yanjiu (Taiwan Historical Research) 24, 3 (2017): 141-208.

Hsiau, A-chin, and Horng-luen Wang, eds. Zuqun minzu yu xiandai guojia. Jingyan yu lilun de fansi (Ethnicity, Nation, and the Modern State: Rethinking Theory and Experience in 
Taiwan and China) (Taipei: Institute of Sociology, Academia Sinica, 2016).

Jones, Paul, and Michał Krzyżanowski. 'Identity, belonging and migration: beyond constructing "others"'. In Identity, Belonging and Migration. Edited by Gerard Delanty (Liverpool: Liverpool University Press, 2008).

Kümmerling-Meibauer, Bettina. 'From baby books to picturebooks for adults: European picturebooks in the new millenium'. Word \& Image 31, 3 (2015): 249-64.

Lent, John A. Asian Comics (Jackson: University Press of Mississippi, 2015).

Li, Yiyun. Manhua de wenhua yanjiu. Bianxing, xianghui yu fuhaohua de xipu (Cultural Studies of Comics. Tracing Changes in Form, Image Symbolism and Semiotic Representation) (New Taipei: Daotian, 2012).

Liu Jessie, Ssu-fang. 'From visual discoveries to bodily trajectories: the insular epistemology of around-the-island journeys in Taiwan cinema'. East Asian Journal of Popular Culture 3, 2 (2017): 199-213.

Malek, Amy. 'Memoir as Iranian exile cultural production: a case study of Marjane Satrapi's Persepolis series'. Iranian Studies 39, 3 (2006): 353-80.

Massey, Doreen. Space, Place and Gender (Minneapolis: University of Minnesota Press, 2001).

Merriman, Peter, and Rhys Jones. 'Nations, materialities and affects'. Progress in Human Geography 41, 5 (2017): 600-17.

Mirzoeff, Nicholas. How to See the World. An Introduction to Images, from Self-Portrait to Selfies, Maps to Movies, and More (New York: Basic Books, 2016).

Munasinghe, Viranjini. 'Nationalism in hybrid spaces: the production of impurity out of purity'. American Ethnologist 29 (August 2002): 663-92.

Muyard, Frank. 'The formation of Taiwan's new national identity since the end of the 1990s'. In Taiwan Since Martial Law: Society, Culture, Politics, Economy. Edited by David Blundell (Taipei: National Taiwan University Press, 2012).

Muyard, Frank. 'Comparativism and Taiwan Studies: analyzing Taiwan in/out of context, or Taiwan as an East Asian new world society'. In Comparatizing Taiwan. Edited by Shu-mei Shih and Pinghui Liao (Abingdon: Routledge, 2015), 13-32.

Phillips, Nelson, and Cynthia Hardy. Discourse Analysis. Investigating Processes of Social Construction (Thousand Oaks: Sage Publications, 2002).

Rigger, Shelley. Taiwan's Rising Nationalism: Generations, Politics and 'Taiwanese Nationalism (Washington: East-West Center, 2006).

Sandel, Todd L., and Chung-hui Liang. 'Taiwan's fifth ethnic group: a study of the acculturation and cultural fusion of women who have married into families in Taiwan'. Journal of International and Intercultural Communication 3 (August 2010): 249-75. Shih, Shu-mei. 'Forum 2: linking Taiwan Studies with the world'. International Journal of Taiwan Studies 1 (2018): 209-27. 
Storm, Carsten, ed. Connecting Taiwan (Abingdon: Routledge, 2018).

Tang, Soupy. Genzhe Soupy fangsong, together (Relax with Soupy) (Taipei: Uni-Books, 2015).

Urry, John, and Jonas Larsen. The Tourist Gaze 3.0 (Los Angeles: Sage Publications, 2011). Varughese, E. Dawson. Visuality and Identity in Post-Millennial Indian Graphic Narratives (Houndmills: Palgrave Macmillan, 2018).

Wang, Fu-chang. Dangdai Taiwan shehui de zuqun xiangxiang (Ethnic Imagination in Contemporary Taiwan) (Taipei: Qunxue, 2003).

Worden, Daniel. The Comics of Joe Sacco: Journalism in a Visual World (Jackson:

University Press of Mississippi, 2015).

Yeh, Emilie Yueh-Yu. 'Elvis, allow me to introduce myself: American music and neocolonialism in Taiwan cinema'. Modern Chinese Literature and Culture 15 (Spring 2003): $1-28$.

Zemanek, Adina. 'Getting to know Taiwan: borrowed gaze, direct involvement and everyday life,' in Positioning Taiwan in a Global Context: Being and Becoming, eds. Bi-Yu Chang, Pei-Yin Lin (Abingdon: Routledge, 2019), 161-77.

Zemanek, Adina. 'National history and generational memory - Taiwanese comic books as lieux de mémoire, positions: asia critique, 28, 2 (2020), 389-420.

Zhongguo Shibao bianjibu (China Times Editorial Office), Taiwan guanjianzi: shi'er ge shehui xin dongli (Taiwan Keywords: Twelve New Social Motive Forces) (Taipei: Tianxia yuanjian, 2013). 